\title{
Vertical distributions and trophic interactions of age-0 Atlantic cod and haddock in mixed and stratified waters of Georges Bank
}

\author{
R. Ian Perry, John D. Neilson \\ Department of Fisheries and Oceans, Marine Fish Division, Biological Sciences Branch, Biological Station, St Andrews, New \\ Brunswick, Canada E0G 2 X0
}

\begin{abstract}
Diel changes in the vertical distribution of age-0 (post-larval) Atlantic cod Gadus morhua and haddock Melanogrammus aeglefinus were examined in isothermal and stratified waters of Georges Bank in June 1985. Discrete depth collections every $4 \mathrm{~h}$ indicated that changes in depth were more extensive for cod than haddock. At both sites, cod were predominately near bottom during the day and in midwater at night, although at the stratified site this upward migration may have been limited by the thermocline. Age-0 haddock at the stratified site occurred about the thermocline with little diel change of depth. At the mixed site, haddock were distributed predominately near bottom but were caught throughout the water column during the periods before noon and midnight. Small cod and haddock ( $<30 \mathrm{~mm}$ standard length for cod, $<40 \mathrm{~mm}$ for haddock) were distributed at shallower depths and undertook less extensive migrations than larger fish. Relationships of temperature, salinity, light, tidal current speed and preferred zooplankton prey to the changes in depth distributions were examined. Vertical migrations of cod were related to the diel light cycle at both sites. At the mixed site, the number of haddock caught was inversely related to the mean tidal current speed during the sampling period. Preferred prey, especially the mysid Neomysis americana, may have moved into midwater with haddock during slackened currents, remaining near bottom with cod at other times in daylight. Zooplankton biomass and physiological condition (as Fulton's $K$ ) of cod and haddock were significantly greater at the mixed site. Electivity indices indicated that $N$. americana, which occurred at high densities, was the preferred prey of both fish species at this site. At the stratified site, cod and its preferred prey Tisbe sp. were both distributed in deep water, while haddock and its preferred prey Limacina sp. co-occurred in near-surface waters. The similar distributions of cod and haddock when prey were plentiful, and separate distributions when prey were scarce, may have served to reduce interspecific competition. Adequate prediction of haddock vertical distributions for survey purposes may require knowledge of thermal structure, distribution of prey, and tidal current speed.
\end{abstract}

\section{INTRODUCTION}

Atlantic cod Gadus morhua and haddock Melanogrammus aeglefinus are important commercial gadid species in the western North Atlantic. On Georges Bank, they undergo considerable interannual variation in recruitment (Hennemuth et al. 1980) which, combined with intense fishing pressure, can lead to recruitment overfishing and stock collapse (e.g. haddock; Overholtz et al. 1986). Recruitment fluctuations of cod and haddock on Georges Bank have generally not covaried (Templeman 1972, Hennemuth et al. 1980), even though these species have similar morphologies and early life histories, the period when year-class strength is believed to be established (May 1974).
The spawning period for cod ranges from December to April and for haddock from February to May on Georges Bank (Colton et al. 1979). Their pelagic eggs and larvae co-occur in the water column and are distributed following the gyral circulation about the Bank (Sherman et al. 1984, Smith \& Morse 1985). By midsummer, at a length of 7 to $8 \mathrm{~cm}$, haddock make the transition to a predominately demersal habit (Koeller et al. 1986). Cod are also believed to make the transition to a predominately demersal habit at about this length, as suggested by changes in diet (Bowman 1981).

Fogarty et al. (1987) have noted there is a significant correlation between the autumn catch of juvenile cod and haddock (age 9 to $18 \mathrm{mo}$ ) and subsequent yearclass strength. However, the numbers of larval 
haddock and subsequent recruits 3 yr later, determined over the period 1974 to 1979 , were only poorly correlated. Sissenwine et al. (1984) have concluded that most of the variability in recruitment occurs during the late larval or post-larval stages, when only a small difference in mortality rate is necessary to account for differences between weak and strong year-classes. Predation on post-larval stages has been proposed as a principal source of mortality leading to this recruitment variability (Sissenwine 1984). Vulnerability to predation can be influenced by growth and food availability (Buckley \& Lough 1987), which is often determined by position in the water column. Differences in prey preferences of juvenile gadids and the availability and distribution of these prey may therefore contribute to different mortalities between age-0 cod and haddock.

One method to improve estimates of numbers of cod and haddock recruiting to the fishery is to survey the juveniles and determine their abundance directly. As a prerequisite to the effective design of such surveys, information on the ecology and behavioural characteristics of the specific life-history stage, such as diel vertical migration, is required (Koeller et al. 1986). This information is generally lacking for post-larval cod and haddock on Georges Bank.

In this paper, we examine the vertical distributions and diel migration patterns of pelagic age-0 cod and haddock on Georges Bank, at locations with contrasting

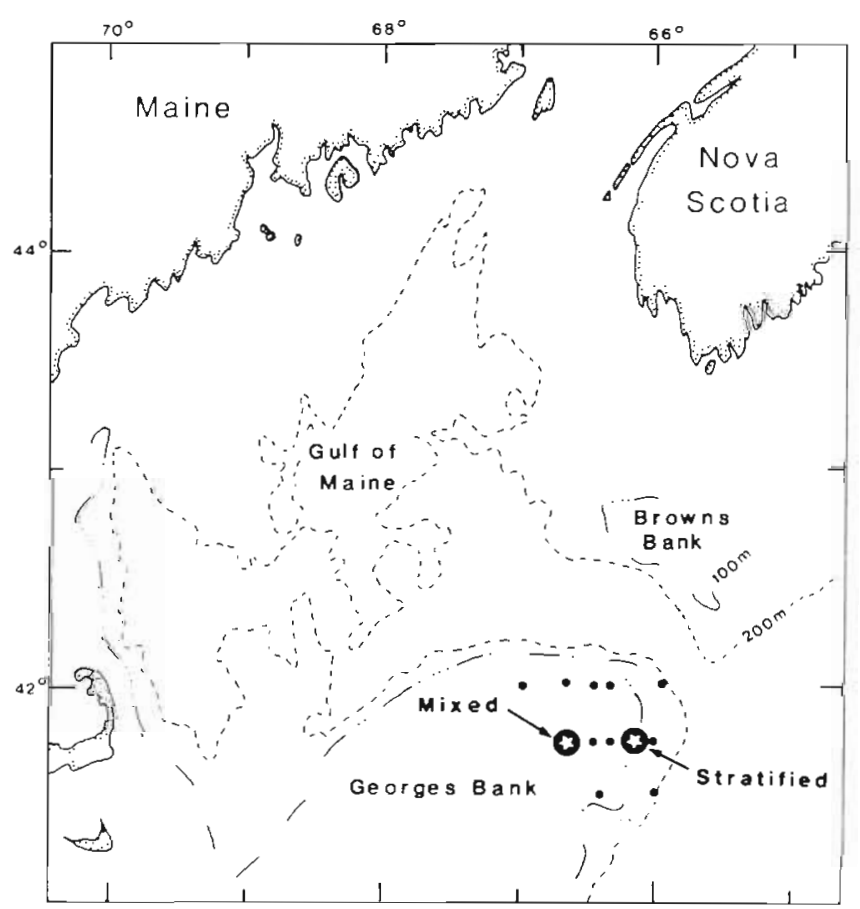

Fig. 1 Location of mixed and stratified sampling sites, Georges Bank, NW Atlantic, June 1985. Small dots indicate the locations of a preliminary CID and mid-water survey for juvenile fish conducted immediately prior to this study oceanographic conditions. These locations, on the mixed and stratified sides of a well-developed tidal front, enabled us to compare vertical distributions under different physical and biological regimes. As one of the potential determinants of vertical distribution and of physiological condition, we also examine the partitioning of food resources between these gadid species.

\section{METHODS}

The study was conducted on the Northeast Peak of Georges Bank, NW Atlantic Ocean, from 22 to 26 June 1985 (Fig. 1). Fishing operations were conducted by the RV 'Alfred Needler' (Cruise N047), while simultaneous oceanographic observations were made from the RV 'Lady Hammond' (Cruise H135). Two stations, ca 40 $\mathrm{km}$ apart, were selected on the bases of their oceanographic characteristics and a preliminary mid-water trawl survey of the northeast peak for suitable concentrations of fish. One station was located at $41^{\circ} 45^{\prime} \mathrm{N}$, $66^{\circ} 10^{\prime} \mathrm{W}$ (bottom depth $80 \mathrm{~m}$ ) in a thermally stratified water mass ('stratified site'), while the other was located at $41^{\circ} 45^{\prime} \mathrm{N}, 66^{\circ} 40^{\prime} \mathrm{W}$ (bottom depth $66 \mathrm{~m}$ ) in an isothermal water mass ('mixed site') (Fig. 1). Additionally, a transect was conducted with a CTD cast every $10 \mathrm{~km}$ between the sites to determine the location of the tidal mixing front.

At each station, sampling was conducted within $4 \mathrm{~h}$ time blocks, which were repeated over $48 \mathrm{~h}(22$ to 24 June 1985) at the mixed site and $24 \mathrm{~h}$ ( 25 to 26 June 1985) at the stratified site. The gear consisted of an International Young Gadid Pelagic Trawl (IYGPT), a large mid-water trawl $38 \mathrm{~m}$ in length, with a mouth opening of ca $100 \mathrm{~m}^{2}$ and with graded mesh from 150 $\mathrm{mm}$ at the mouth to $5 \mathrm{~mm}$ at the cod end. It was towed at a speed of 3.5 knots, which gave a vertical mouth opening of ca $11 \mathrm{~m}$. Within each time block, fish were collected by consecutive $0.5 \mathrm{~h}$ sets at depths of 50,30 , and $15 \mathrm{~m}$, with the catch recovered before setting to the next depth. The time required to set and retrieve the net was less than $3 \mathrm{~min}$. Therefore, relatively little contamination of the catch from other depths is believed to have occurred. All fish collected were identified, counted, and lengths measured from the anterior tip of the jaw to the posterior end of the caudal peduncle (standard length). We defined age-0 cod and haddock to be post-metamorphosis pelagic juveniles, of $\mathrm{ca} 4$ to 6 mo of age given their expected spawning times on Georges Bank (Colton et al. 1979). Numbers of fish caught were standardized to a tow distance of $3.25 \mathrm{~km}$ to reduce variability due to the time or speed of each tow. For large catches ( $>1000$ fish), lengths were measured on a subsample of at least 300 fish and the resulting length-frequency distribution applied to the total 
sample for that species. Random subsamples of age-0 cod and haddock from the stratified site and the first $24 \mathrm{~h}$ series of collections from the mixed site were also preserved in $4 \%$ buffered Formalin for analyses of gut contents in the laboratory.

Oceanographic observations within each $4 \mathrm{~h}$ sampling block consisted of a lightmeter profile to $25 \mathrm{~m}$ using a LiCor Li-188B quantum meter (08:00-20:00 h only), a CTD cast from surface to $5 \mathrm{~m}$ above the bottom to obtain profiles of temperature and salinity, water samples for plant pigment and nutrient analyses, and zooplankton collections using a multiple openingclosing net system (MININESS) (Reid et al. 1987) and $333 \mu \mathrm{m}$ mesh nets. At the mixed site, both water and zooplankton samples were collected from depths of 50 , $40,30,25,20,15,10$, and $5 \mathrm{~m}$, while at the stratified site sample depths were $75,50,40,30,25,20,15,10$, and $5 \mathrm{~m}$ (no zooplankton were sampled from $40 \mathrm{~m}$ at this site). Zooplankton tow duration was $10 \mathrm{~min}$ at each discrete depth, at a tow speed of 2.5 knots. All plankton were preserved in $4 \%$ buffered Formalin. Onshore, zooplankton biomass excluding large gelatinous zooplankton was estimated by measuring the sample displacement volume. All plankton collected were identified to at least genus and counted.

A maximum of 10 fish of each species (minimum of 5 cod and 2 haddock) from each depth and time combination at the stratified site and the first $24 \mathrm{~h}$ at the mixed site were examined and their gut contents identified to the lowest possible taxon. A total of $408 \mathrm{cod}$ and 302 haddock guts were examined. In addition, dry weights of gut contents from a maximum of 5 fish of each species, depth, and time combination were determined by drying the contents for $48 \mathrm{~h}$ at $60^{\circ} \mathrm{C}$, then weighing with a Cahn electrobalance. These weights were then divided by the standard length of the fish to remove size effects. To examine whether condition varied at the stratified and mixed sites, we made morphometric measurements [Fulton's $K$ (weight/length ${ }^{3}$ ) and body height] on $240 \mathrm{cod}$ and 184 haddock. For cod and where possible for haddock, 20 fish from each of the 3 depths sampled and from both day (12:00-16:00 h) and night (00:00-04:00 h) were randomly removed from sample jars. The standard lengths of the preserved fish were corrected for average shrinkage, using factors obtained from successive remeasurement of 60 other specimens of each species, individually preserved (correction factors were 1.16 and 1.18 for cod and haddock, respectively). Body height was measured using a dissecting microscope, and was taken at the insertion of the pectoral fin. Weights were recorded wet, after careful blotting with absorbent paper.

Variation in the depth distribution of animals within each time block were evaluated by calculating weighted mean depths $\left(Z_{m}\right)$ :

$$
Z_{m}=\frac{\sum n_{i} Z_{i}}{\sum n_{i}}
$$

where $n_{i}=$ number of a species at depth $Z_{i}$ (Pearre 1973). This index is based only on those animals caught at the sampled depths, and does not include distributions beyond these depths.

Zooplankton taxonomic diversity at a given site was calculated using the Shannon diversity index:

$$
H^{\prime}=-\sum p_{i} \log _{2} p_{i}
$$

with $p_{t}=n_{1} / N$ where $n_{i}$ is the number of the $i$ th species and $N$ is the total number of individuals (Shannon \& Weaver 1963). This index ranges from 0 when only one species is present, to $H_{\max }^{\prime}$, which is the value when all species are equally abundant. The niche breadth index, used to quantify the range of prey items taken by age- 0 cod and haddock, is defined in analogous fashion:

$$
B^{\prime}=-\sum p_{1} \ln p_{i} ; \quad p_{1}=n_{1} / N
$$

with $B_{\max }^{\prime}$ the niche breadth if all prey items were equally abundant (Colwell \& Futuyma 1971). The niche overlap index, used to compare the similarity of prey composition between cod and haddock at each site, is defined as:

$$
D=1-0.5\left(\Sigma_{1}\left|p_{x i}-p_{y i}\right|\right)
$$

with $p_{x i}$ the proportion of prey category $i$ in the diet of species $X$, and $p_{y z}$ that in the diet of species $Y$ (Hurlbert 1978). A value of 0 for this index represents no overlap. a value of 1 represents complete overlap.

The preferences of age-0 cod and haddock for particular prey groups were estimated based on the

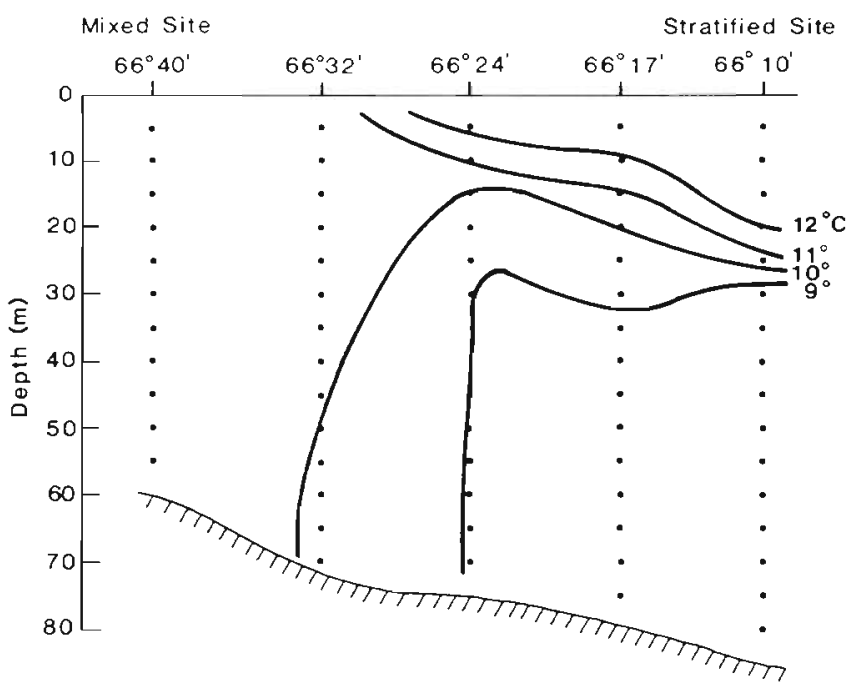

Fig. 2. Thermal section between mixed and stratified sites along latitude $41^{\circ} 45^{\prime} \mathrm{N}$ conducted on 26 June 1985. CTD profiles (represented by vertical dots) were located ca $10 \mathrm{~km}$ apart. Numbers across the top refer to West longitude 
number of prey in the gut contents and their abundance in the plankton. We used a $\chi^{2}$-based index proposed by Pearre (1982)

$$
C= \pm\left(\frac{X_{v}^{2}}{n}\right)^{1 / 2} \text { with } X_{v}^{2}=\frac{n\left(\left|a_{d} b_{e}-b_{d} a_{e}\right|-\frac{n}{2}\right)^{2}}{a b d e}
$$

where $a_{d}=$ the number of taxon $i$ in the diet; $b_{d}=$ the number of all other taxa in the diet; $a_{e}=$ the number of taxon $i$ in the environment; $b_{\epsilon^{\prime}}=$ the number of all other taxa in the environment; $a=a_{d}+a_{e} ; b=b_{d}+b_{e} ; d=$ $a_{d}+b_{d i} e=a_{e}+b_{e}$; and $n=a+b$. The sign of $C$ is determined by the term inside the absolute value sign. The range of $C$ is \pm 1 , for positive or negative selection, and may be tested for significance with $n \mathrm{Cl}$ and tables of the normal deviate $(Z)$.

To examine whether differences in light intensity between the 2 sites were correlated with vertical migratory behaviour of cod and haddock, we calculated the depth of a critical light intensity at each site. The critical light intensity was 0.01 to 1 lux (the lower limit is equivalent to $10^{-4} \mu \mathrm{E} \mathrm{m}^{-2} \mathrm{~s}^{-1}$ at $550 \mathrm{~nm}$ ), which was suggested by Blaxter (1965) as the intensity at which visual feeding by adult cod ceases. Using the measured light intensity just beneath the surface $\left(I_{0-}\right)$ and the attenuation coefficient $(k)$, this depth was calculated from:

$$
Z=\frac{\ln I_{0-}-\ln \left(10^{-4}\right)}{k}
$$

Tidal current velocities have been modelled for the Gulf of Maine and Georges Bank by Greenberg (1983). This model predicts the current velocities due to the $M_{2}$ tidal component, which is the strongest component on Georges Bank (Butman \& Beardsley 1987), on a grid of ca $7 \mathrm{~km}$ spacing. It has been used successfully to predict the location of tidal mixing fronts in this region (Loder \& Greenberg 1986). We used amplitude and phase information from this model kindly provided by D. Greenberg and J, Loder (Bedford Institute of Oceanography, Dartmouth, N.S., Canada, pers, comm.) for the location of the mixed site to calculate the $M_{2}$ tidal current speeds throughout the period of sampling.

\section{RESULTS}

\section{Physical oceanographic characteristics}

The mixed station remained isothermal with temperatures $10^{\circ} \mathrm{C} \pm 1 \mathrm{C}^{\circ}$ during the $48 \mathrm{~h}$ sampled (Fig. 2). Vertical salinity profiles were similar to that for temperature, with no strong gradients. During the $24 \mathrm{~h}$ sampled at the stratified site, temperatures ranged

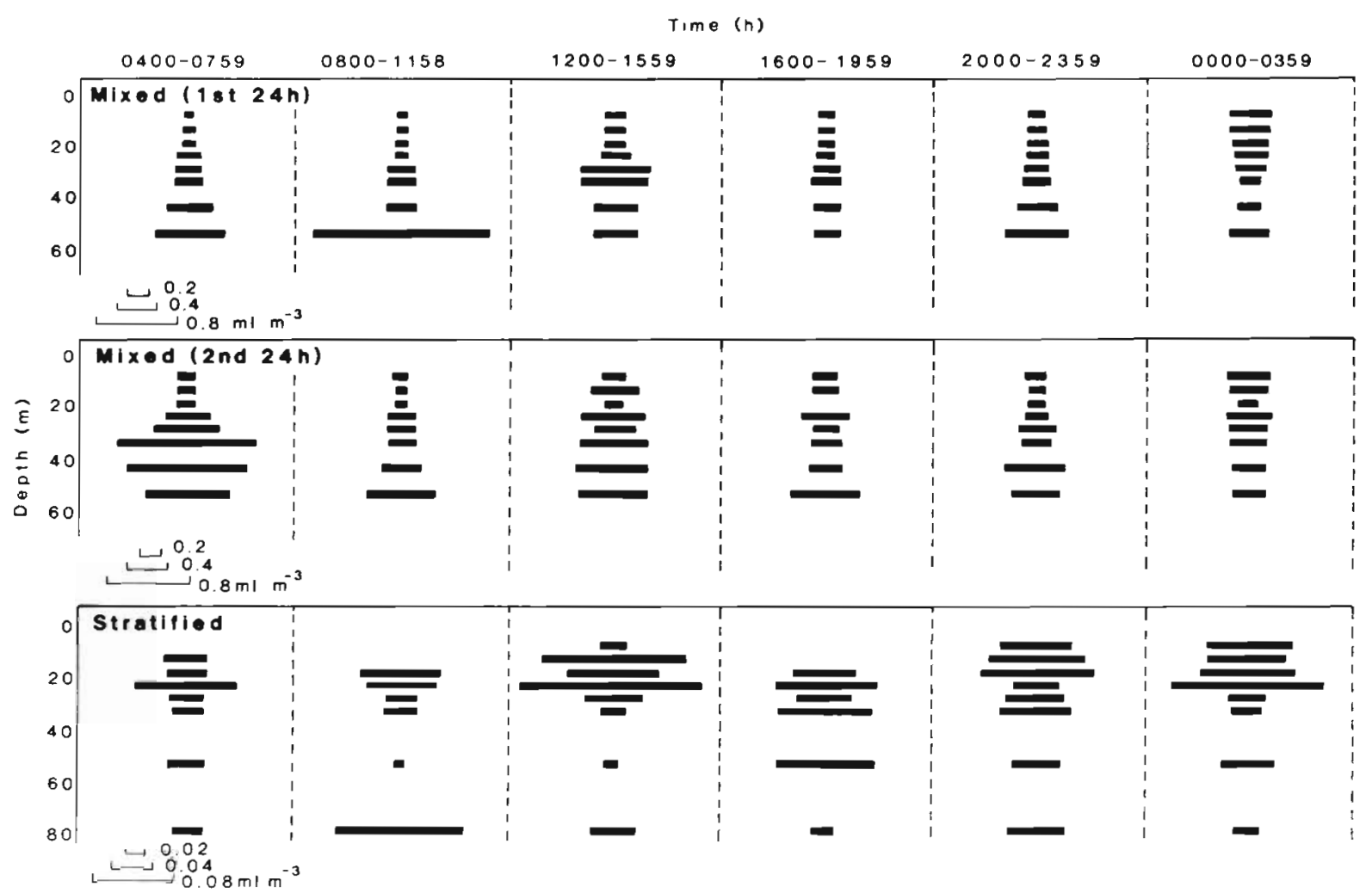

Fig. 3. Zooplankton displacement volumes at mixed and stratified sites, Georges Bank, June 1985. The $48 \mathrm{~h}$ sampled at the mixed site are divided into two $24 \mathrm{~h}$ segments. Bottom depths were $66 \mathrm{~m}$ at the mixed site, $80 \mathrm{~m}$ at the stratified site 
from $13^{\circ} \mathrm{C}$ at the surface to $8^{\circ} \mathrm{C}$ at $30 \mathrm{~m}$, with a thermocline evident between 15 and $30 \mathrm{~m}$ (Fig. 2). The results of the CTD transect between these stations indicate they were approximately equidistant from the welldeveloped tidal front encircling the cap of Georges Bank (Fig. 2).

Attenuation coefficients $(k)$ for visible light (400 to $700 \mathrm{~nm}$ ) over the upper $25 \mathrm{~m}$ at the mixed site ranged from 0.17 to 0.19 during the day, and from 0.23 to 0.30 in the early evening due to increased surface scatter caused by the low sun angle. The coefficients were similar at the stratified site, with midday values of 0.19 to 0.20 , and morning and evening values of 0.22 to 0.24 .

\section{Biological oceanographic characteristics}

Zooplankton biomass, measured as displacement volume, differed significantly between the 2 sites ( $t$ test, $p<0.01$ ). The mean displacement volume for each

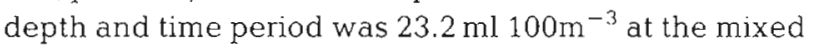

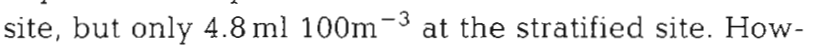
ever, zooplankton diversity, using the Shannon diver- sity index $H^{\prime}$, was greater at the stratified site than at the mixed site:

\begin{tabular}{lcc} 
& $H^{\prime}$ & $H_{\max }$ \\
\hline Stratified site & 3.97 & 6.09 \\
Mixed site (1st 24 h) & 2.77 & 6.15 \\
Mixed site (2nd 24 h) & 2.76 & 6.05
\end{tabular}

The vertical distributions of zooplankton biomass over time also differed between sites (Fig. 3). At the stratified site, zooplankton biomass was concentrated about the thermocline, while at the mixed site the depth of zooplankton concentration was more variable.

The mid-water trawl survey conducted prior to the start of this study indicated the highest concentrations of age- 0 gadids occurred at the locations chosen as the mixed and stratified sites. Relatively few cod and haddock were captured at the other stations; mean number per standard tow was 182 cod and 12 haddock

Cod were more abundant than haddock during the $48 \mathrm{~h}$ and $24 \mathrm{~h}$ sampling series at the mixed and stratified sites. Both cod and haddock were more abundant at the mixed site than at the stratified site, particularly haddock:

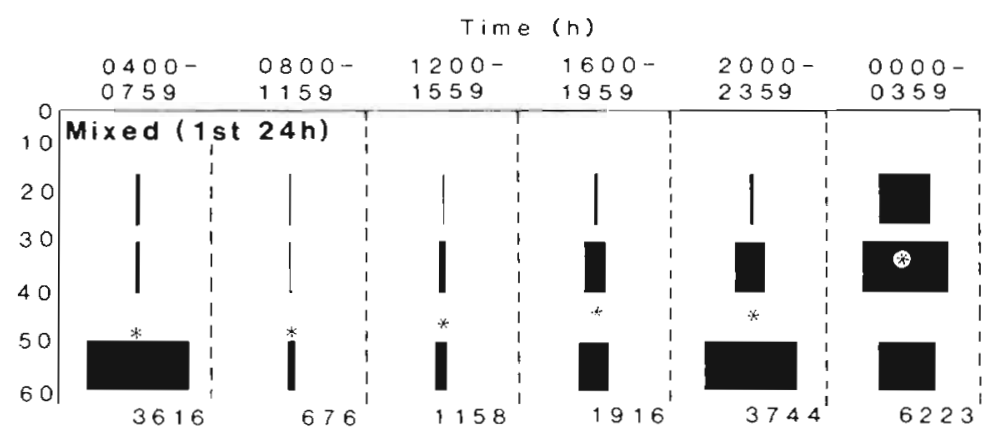

Fig. 4. Gadus morhua vertical distributions at mixed (separated into two $24 \mathrm{~h}$ segments) and stratified sites, Georges Bank, June 1985. The width of each bar is proportional to the number caught standardized to a tow distance of 3.25 $\mathrm{km}$, while the height of each bar represents the depth range sampled during a tow. Numbers at the bottom of each panel indicate the total (standardized) number caught over all depths during that time period. Stars indicate the calculated mean depth of the distribution sampled during each time period
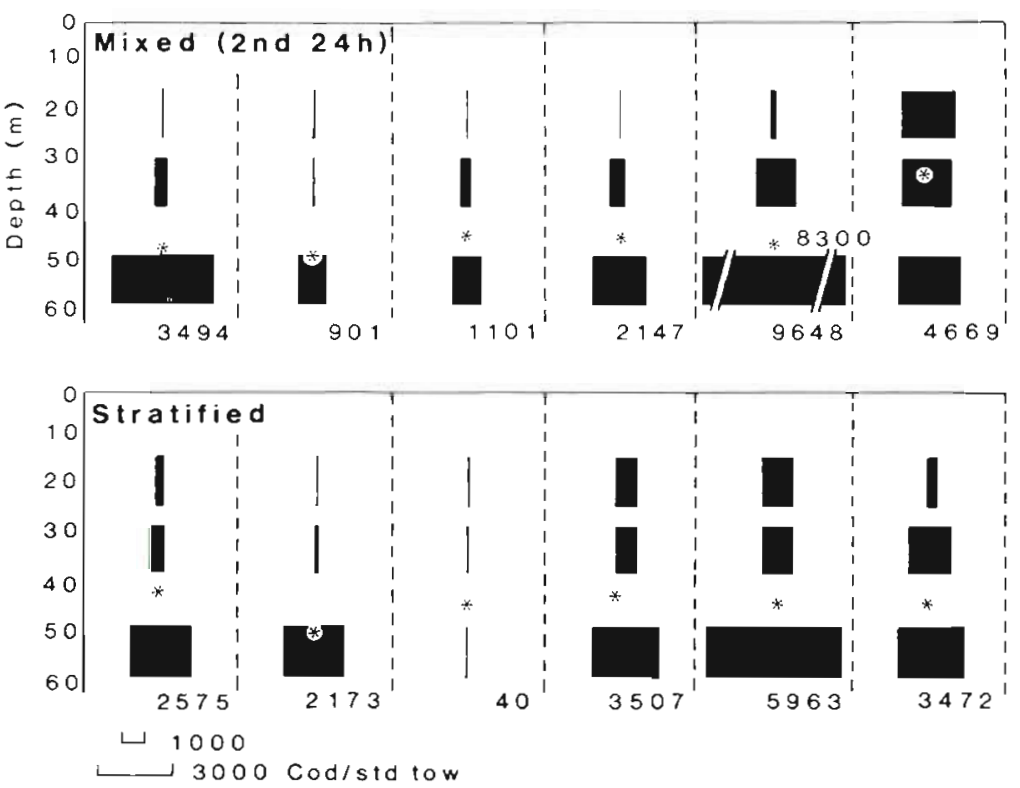


\begin{tabular}{|c|c|c|c|c|}
\hline & \multicolumn{2}{|c|}{ Mixed site } & \multicolumn{2}{|c|}{ Stratified site } \\
\hline & Cod & Haddock & Cod & Haddock \\
\hline $\begin{array}{l}\text { Total nos. caught } \\
\text { (average for } 24 \mathrm{~h} \text { ) }\end{array}$ & 19646 & 4622 & 17730 & 420 \\
\hline Median length $(\mathrm{mm})$ & 32.9 & 46.5 & 37.3 & 46.0 \\
\hline
\end{tabular}

Cod were significantly (ANOVA, $p<0.05$ ) larger at the stratified site than the mixed site, while haddock were approximately the same size at both sites (ANOVA, $p>0.05$ ). Haddock were larger than cod at both sites.

Fish other than Atlantic cod and haddock comprised

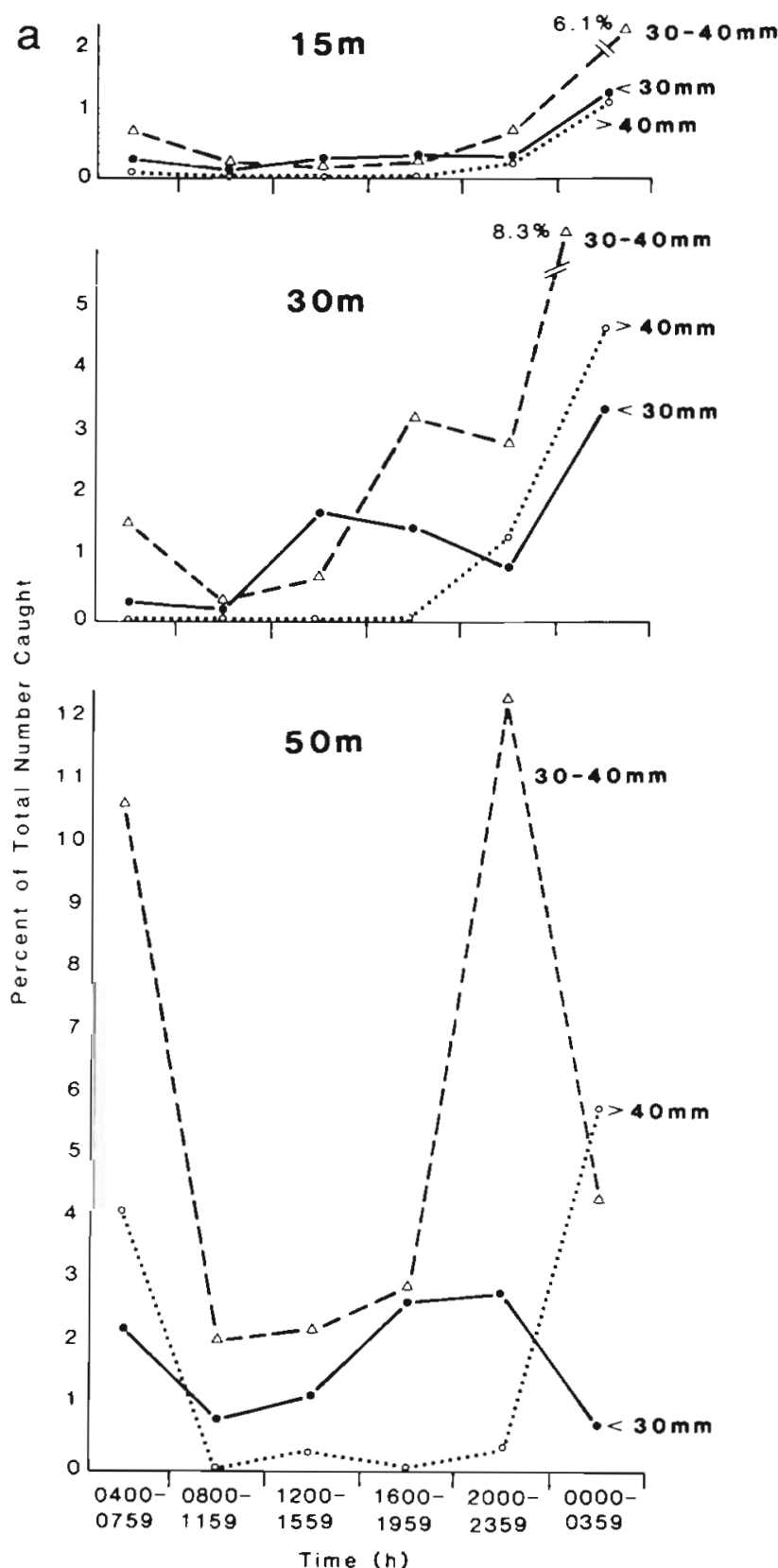

less than $10 \%$ of the total number of fish caught at each site.

\section{Vertical distributions - cod}

The vertical distributions of age- 0 cod over time were similar at the mixed and stratified sites (Fig. 4). At the mixed site, cod were distributed deeper in the water column during the day, at progressively shallower depths during the afternoon, and throughout the water b
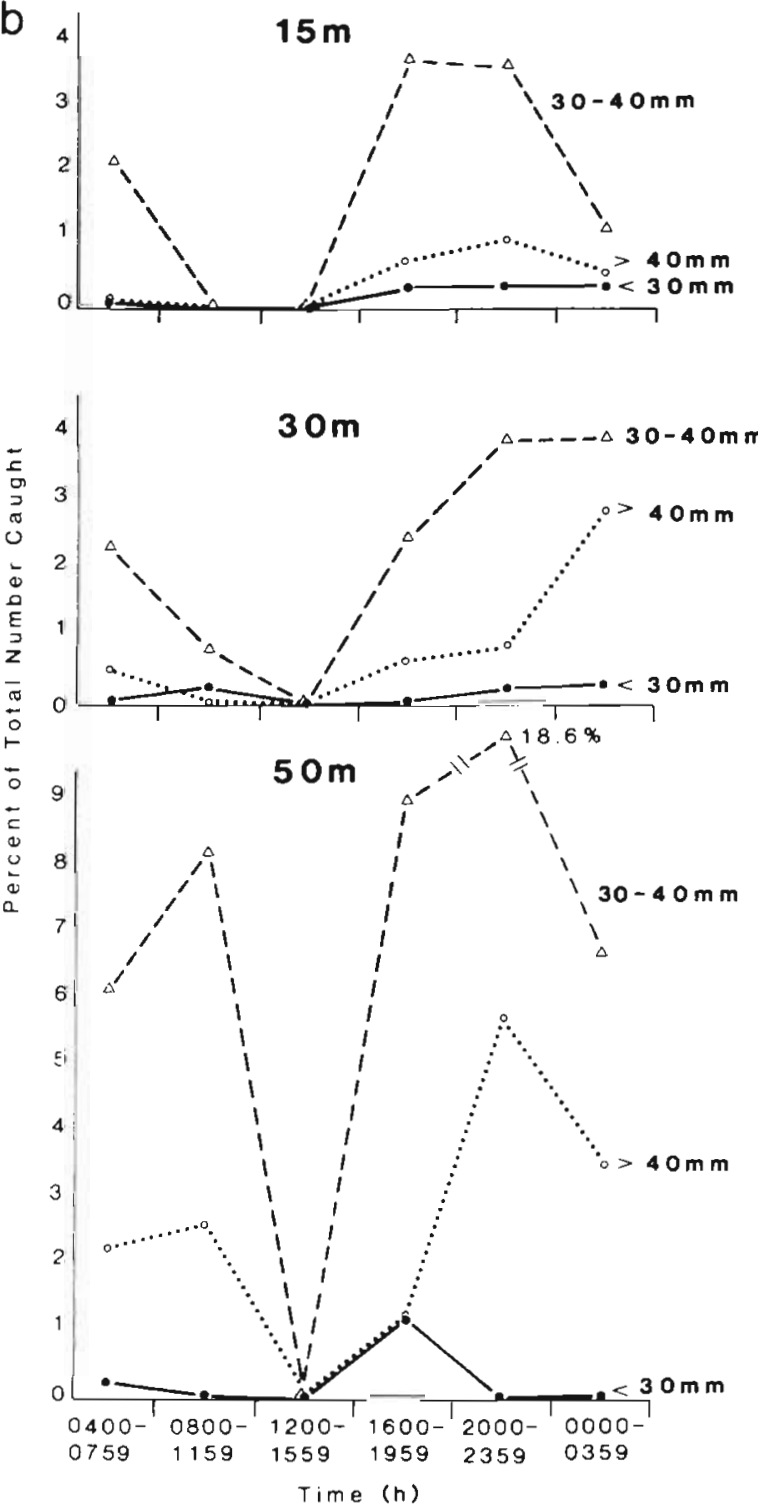

Fig. 5. Gadus morhua size and depth distributions over time at muxed (a) and stratified (b) sites, Georges Bank, June 1985. Sizeclasses are represented by standard lengths. Each point indicates the percent of the total number of Atlantic cod caught during 24 h sampling, by time, depth, and size-class. Total (standardized) number caught for (a) 17 333, for (b) 17730 
column at night. This pattern was consistent over the two $24 \mathrm{~h}$ sampling periods at this site. The mean depth indices summarize the diel changes, with distributions being deep $(>40 \mathrm{~m}$ ) during the day and in mid-water $(<40 \mathrm{~m})$ at night.

At the stratified site, relatively few cod were caught at the 3 depths sampled during the midday period and we infer that they were distributed deeper in the water column during the day. At night, greater numbers were caught at all depths, although the proportion at the deepest depth was larger than at the mixed site. This is demonstrated by the mean depth indices (Fig. 4), which remained below $40 \mathrm{~m}$ at the stratified site compared with the mixed site during the 00:00-04:00 h period.

Diel variations in the vertical distributions at both sites are corroborated by the variation in the total numbers caught (Fig. 4). Significantly greater catches occurred at both sites during the night ( $t$-test, $p<0.01$ ). There was also a size-related component to the diel variation in catches. During the day, fish larger than $40 \mathrm{~mm}$ occurred in deep water only, but were caught at all depths during the night. Fig. 5 shows the proportion of age-0 cod captured at each depth and time period for 3 size categories, representing the approximate lower and upper $30 \%$ and middle $40 \%$ of the size distribution. At the mixed site (Fig. 5a) at night, cod of all sizes occurred at the 3 depths in high proportions. During the day, however, large cod $(>40 \mathrm{~mm})$ were either absent or occurred in tows from $50 \mathrm{~m}$ only. At the stratified site (Fig. 5b), age-0 cod of all sizes occurred throughout the water at night. During the day, e.g. 12:00-16:00 h, the few cod caught at 15 and $30 \mathrm{~m}$ were $<40 \mathrm{~mm}$, while fish $>40 \mathrm{~mm}$ were caught only at $50 \mathrm{~m}$.

\section{Vertical distributions - haddock}

The diel vertical distributions of age-0 haddock differed between the 2 sites (Fig. 6). At the stratified site, haddock occurred generally above $40 \mathrm{~m}$, and the mean depth indices remained between 20 and $30 \mathrm{~m}$, within the depth range of the thermocline. There was also no significant variation in numbers of fish caught between day and night periods ( $t$-test, $p>0.05$ ).

At the mixed site, however, haddock were distributed deeper than $40 \mathrm{~m}$, with no indication of greater numbers throughout the water column at night (cf. cod, in particular the 00:00-04:00 h period; Fig. 4). Instead,
Fig. 6. Melanogrammus aeglefinus vertical distributions at mixed (separated into two $24 \mathrm{~h}$ segments) and stratified sites, Georges Bank, June 1985. The width of each bar is proportional to the number caught standardized to a tow distance of $3.25 \mathrm{~km}$, while the height represents the depth range sampled during a tow. Numbers at the bottom of each panel indicate the total (standardized) number caught over all depths during that time period. Stars indicate the mean depth of the sampled distribution for each time period
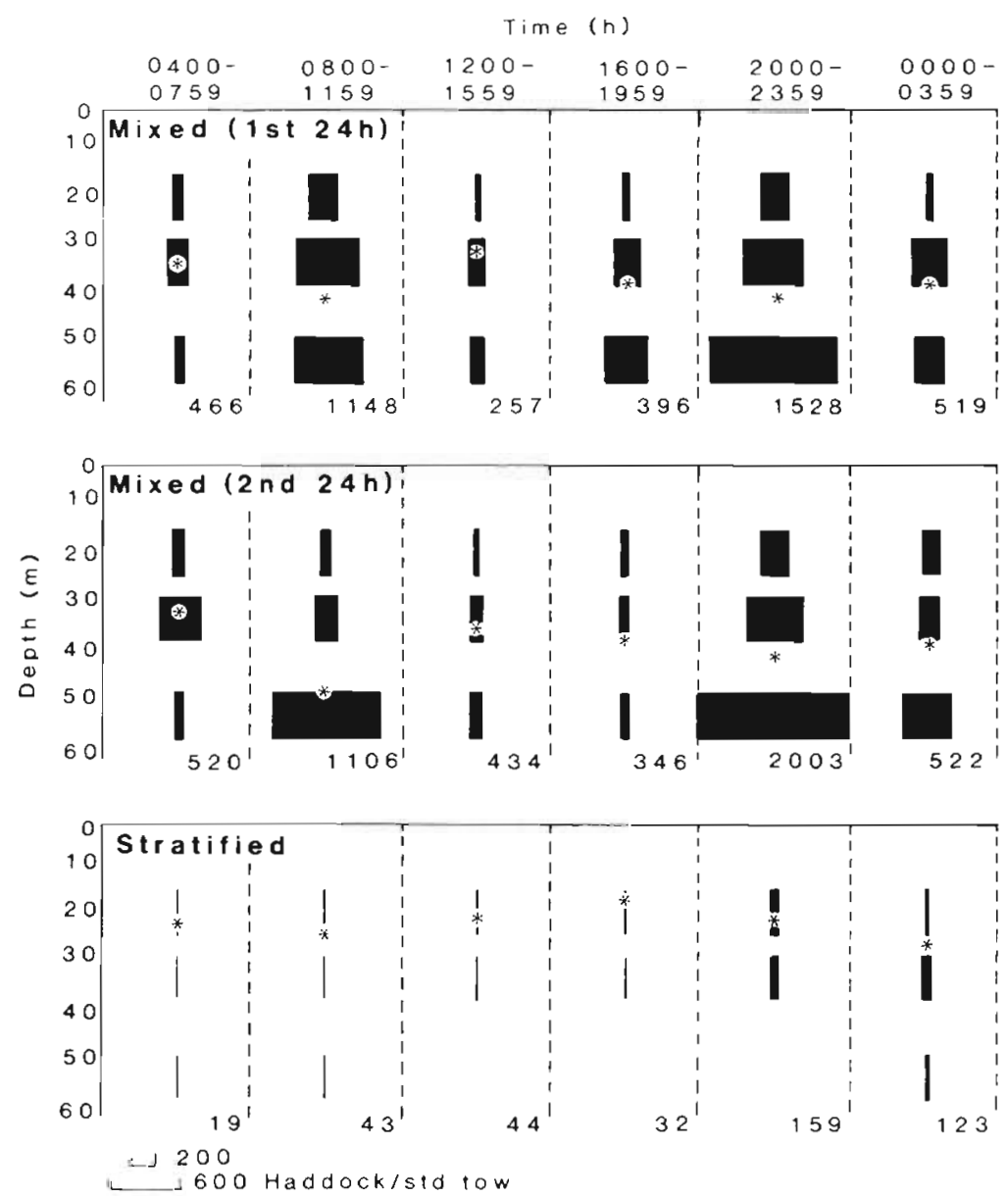

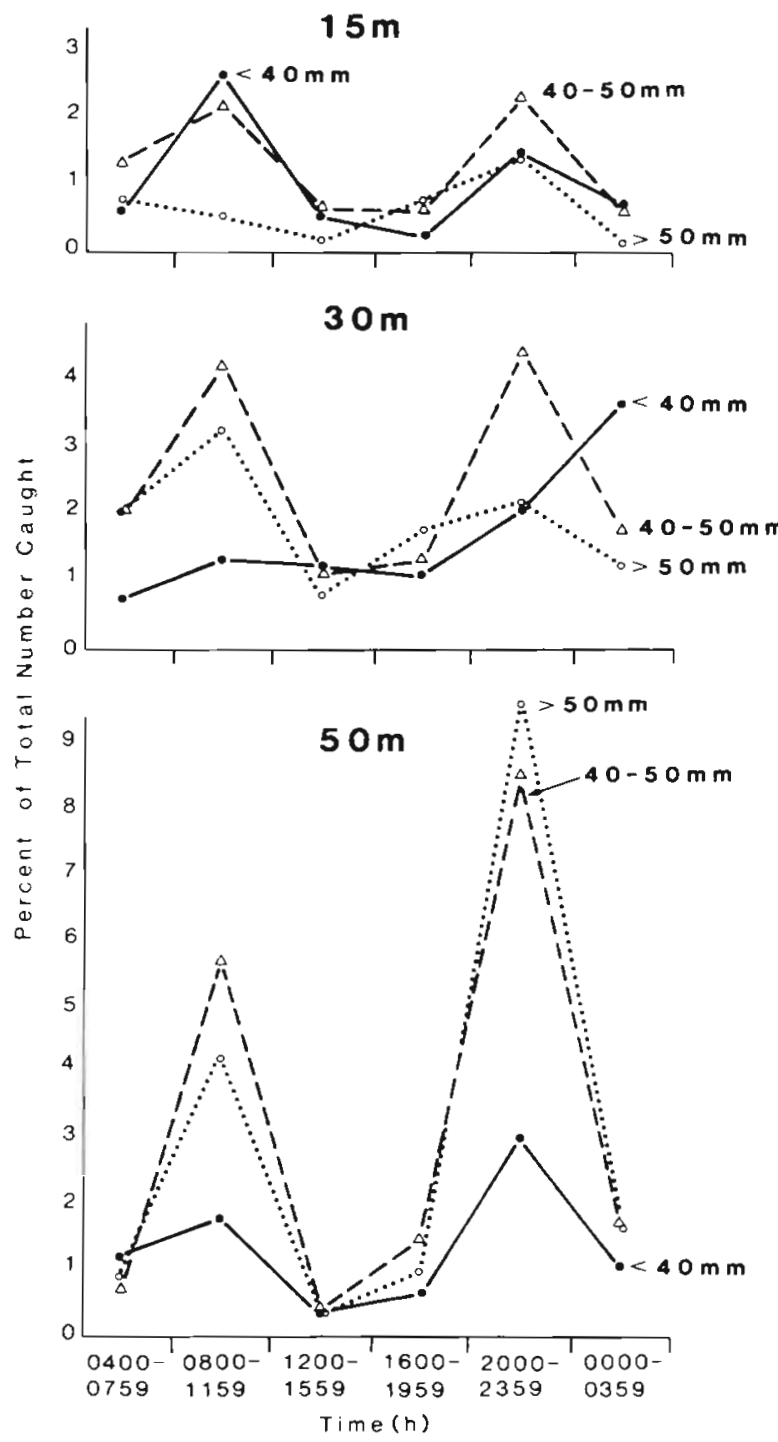

Fig. 7 Melanogrammus aeglefinus size and depth distributions over time at the mixed site, Georges Bank, June 1985 Size-classes are represented by standard lengths. Each point indicates the percent of the total number of haddock caught during the first $24 \mathrm{~h}$ sampled, by time, depth and size-class.

Total (standardized) numbers caught were 4314 greater numbers of haddock were caught during the 2 time periods 08:00-12:00 h and 20:00-00:00 h, predominately in near-bottom waters but also to some extent in mid-water. This pattern is consistent over the $48 \mathrm{~h}$ sampled at this site. Catches of haddock during these 2 time periods are over 2.5 times the catches during night, and 4 times the catches during day (Fig. 6). Excluding these 2 periods, the numbers caught are not statistically different ( $t$-test, $p>0.05$ ) between night and day.

There was also a size-related component to the diel changes in numbers of haddock at the mixed site. The percentage of the total number of haddock caught over the first $24 \mathrm{~h}$ at the mixed site is shown in Fig. 7 for each time and depth combination, separated into 3 classes representing the upper and lower $30 \%$ and middle $40 \%$ of the size distribution of haddock caught. The size classes are different to those employed for cod,

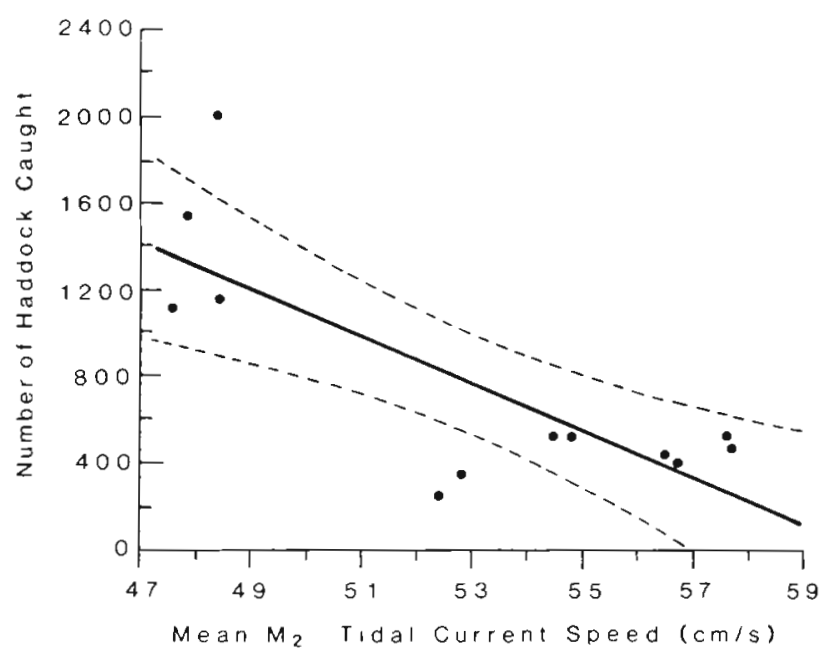

Fig. 8. Melanogrammus aeglefinus. Regression of standardized number of haddock caught within each $4 \mathrm{~h}$ time period at the mixed site vs the mean $M_{2}$ tidal current speed during the same time period, Georges Bank, June 1985. The regression is significant $(p<0.01), r^{2}=0.61, n=12$. Dashed lines represent $99 \%$ confidence intervals

Table 1. Gadus morhua. ANOVA table for a 3 -factor analysis of variance on Fulton's $K$, an index of condition, using the independent terms, site, depth and time; Georges Bank, 1985

\begin{tabular}{lrrrrr}
\hline Source & df & Sum of squares & Mean square & F-test & $p$ value \\
\hline Site $(A)$ & 1 & 559.928 & 559.928 & 5.781 & 0.0170 \\
Depth $(B)$ & 2 & 7071.616 & 3535.808 & 36.505 & 0.0001 \\
AB & 2 & 13044.715 & 6522.358 & 67.340 & 0.0001 \\
Time $(C)$ & 1 & 1157.857 & 1157.857 & 11.954 & 0.0007 \\
AC & 1 & 3334.914 & 3334.914 & 34.431 & 0.0001 \\
BC & 2 & 3166.597 & 1583.298 & 16.347 & 0.0001 \\
ABC & 2 & 1606.539 & 803.269 & 8.293 & 0.0003 \\
Error & 228 & 22083.465 & 96.857 & & \\
\hline
\end{tabular}


Table 2. Melanogrammus aeglefinus. ANOVA table for a 2-factor analysis of variance on Fulton's $K$, an index of condition, using the independent terms, site and depth; Georges Bank, 1985

\begin{tabular}{lrccrc|}
\hline Source & df & Sum of squares & Mean square & F-test & $p$ value \\
\hline Site (A) & 1 & 0.469 & 0469 & 49.982 & 0.0001 \\
Depth (B) & 2 & 0.003 & 0.001 & 0.138 & 0.8710 \\
AB & 2 & 0.002 & 0.001 & 0.093 & 0.9115 \\
Error & 178 & 1.672 & 0.009 & & \\
\hline
\end{tabular}

reflecting the larger mean length of haddock. At 50 and $30 \mathrm{~m}$, the over 2 -fold increase in numbers during the times 08:00-12:00 h and 20:00-00:00 h were due predominately to haddock $>40 \mathrm{~mm}$ in length, although a greater proportion of fish (up to $20 \%$ of the total catch) occurred at night at $50 \mathrm{~m}$. At $15 \mathrm{~m}$ there was little increase in the catch of large haddock (>50 mm) during the day although there was a slight increase at night. The largest proportion of haddock at $15 \mathrm{~m}$ during the 08:00-12:00 $\mathrm{h}$ period was of fish $<40 \mathrm{~mm}$ in length. This pattern was repeated during the second $24 \mathrm{~h}$ sampled at this site. At the stratified site, little variation in size of fish occurred between depths over the time periods sampled although fish $>50 \mathrm{~mm}$ were caught in greater abundance (up to $12 \%$ of the total) at night.

Modelled tidal current speeds at the location of the mixed station were averaged within each $4 \mathrm{~h}$ sampling block. This produced a mean tidal current speed for each sample period over the $48 \mathrm{~h}$ at the mixed site. The relationship between the mean tidal current speed $(X)$ and the number of haddock caught $(Y)$ during each time period was an inverse one yielding the equation $Y=6483-108 X\left(x^{2}=0.61, p<0.01\right.$; Fig. 8$)$. The 2 time periods when greater numbers of haddock were caught (08:00-12:00 h and 20:00-00:00 h) correspond to the periods with lowest mean tidal current speeds.

\section{Trophic interactions}

Variation in cod condition was dependent on site, time and depth. The condition of fish at the mixed site, measured as Fulton's $K$, was significantly higher, on the average, than that of fish at the stratified site (3-way analysis of variance, $p<0.05$; Table 1 ). No difference was detected using body height as an indicator of condition (3-way analysis of variance, $p>0.05$ ). In haddock, it was possible to examine condition as a function of site and time only, due to the absence of haddock at certain depths at the stratified site. In that instance, both indicators of condition were significantly

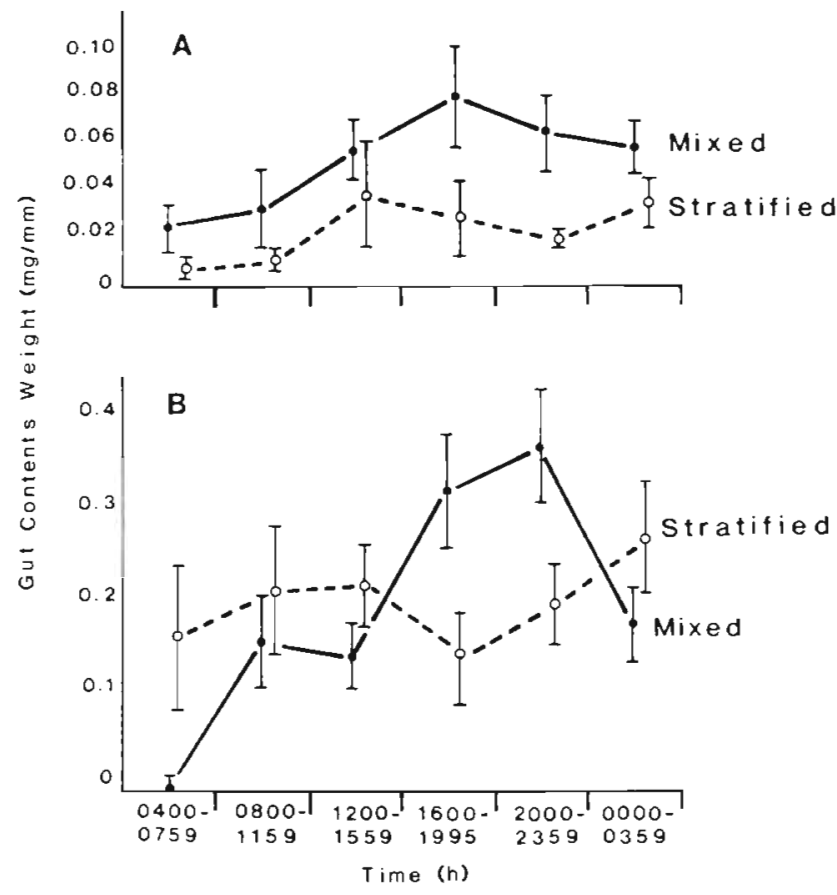

Fig. 9. Gadus morhua and Melanogrammus aeglefinus. Dry weight of gut contents standardized for fish length of (A) Atlantic cod and (B) haddock at the mixed and stratified sites, Georges Bank, June 1985. Points represent the mean of 5 samples; error bars indicate \pm 1 standard error of the mean

Table 3. Melanogrammus aeglefinus. ANOVA table for a 2-factor analysis of variance on body height/length, an index of condition, using the independent terms, site and depth; Georges Bank, 1985

\begin{tabular}{|lrccrc|}
\hline Source & df & Sum of squares & Mean square & F-test & $p$ value \\
\hline Site (A) & 1 & 0.08 & 0.080 & 13.070 & 0.0004 \\
Depth (B) & 2 & 0.01 & 0.005 & 0.797 & 0.4522 \\
AB & 2 & 0.01 & 0.005 & 0.802 & 0.4503 \\
Error & 178 & 1.083 & 0.006 & \\
\hline
\end{tabular}




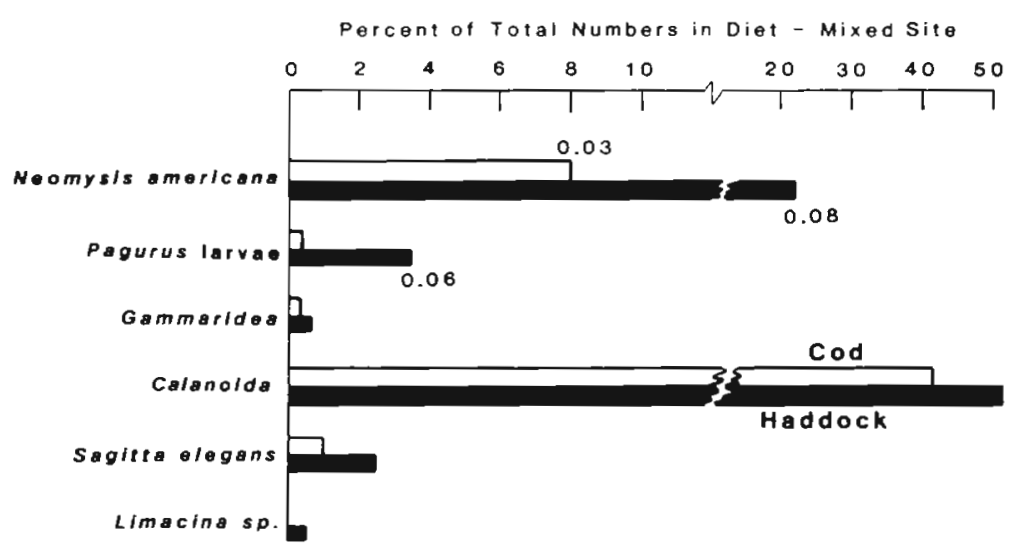

Fig. 10. Gadus morhua and Melanogrammus aeglefinus. Zooplankton prey composition of gut contents of Atlantic cod and haddock from the mixed site, Georges Bank, June 1985. Only zooplankton occurring in $\geq 5 \%$ of the guts examined are included. Total number of guts examined were 179 cod and 172 haddock $_{\text {i total }}$ number of prey items identified were 5382 from cod, 3962 from haddock. Numbers at the end of the histogram bars represent the value of a $\chi^{2}$ based electivity index (see text) for that taxonomic group and fish species. Only those values significantly different from 0 and $>0.01$ are included

higher at the mixed site $(p<0.01$ for both Fulton's $K$ and body height standardized for length; Tables 2 and 3 ).

Feeding periodicity differed between the 2 species. Fig. 9 indicates the weight of the gut contents standardized for fish length for cod and haddock at each site. Haddock had, in general, higher gut contents weight than cod, particularly at the stratified site. Assuming that strong positive slopes indicate periods with higher rates of food consumption, we conclude that cod were feeding predominately in the afternoon and early evening, during the 12:00-16:00 $\mathrm{h}$ and 16:00-20:00 $\mathrm{h}$ time blocks at the mixed site, and the 12:00-16:00 h time block at the stratified site. Haddock had 2 periods of pronounced feeding activity, in the morning
(08:00-12:00 h) and in the evening (16:00-00:00 h) at the mixed site. At the stratified site, the evening feeding period occurred later (20:00-04:00 h). Additionally, the increase in gut contents weight was larger for haddock at the mixed site than at the stratified site. The feeding periods indicated by these data are corroborated by the occurrence over time of empty guts, which were minimal during the 16:00-20:00 h period for cod at both sites $(0 \%$ mixed, $10 \%$ stratified $)$, and for haddock during the midday and midnight time blocks $(<5 \%)$. Empty guts also occurred more frequently with cod in all time blocks at the stratified compared with the mixed site, while they occurred with similar frequency between sites for haddock.

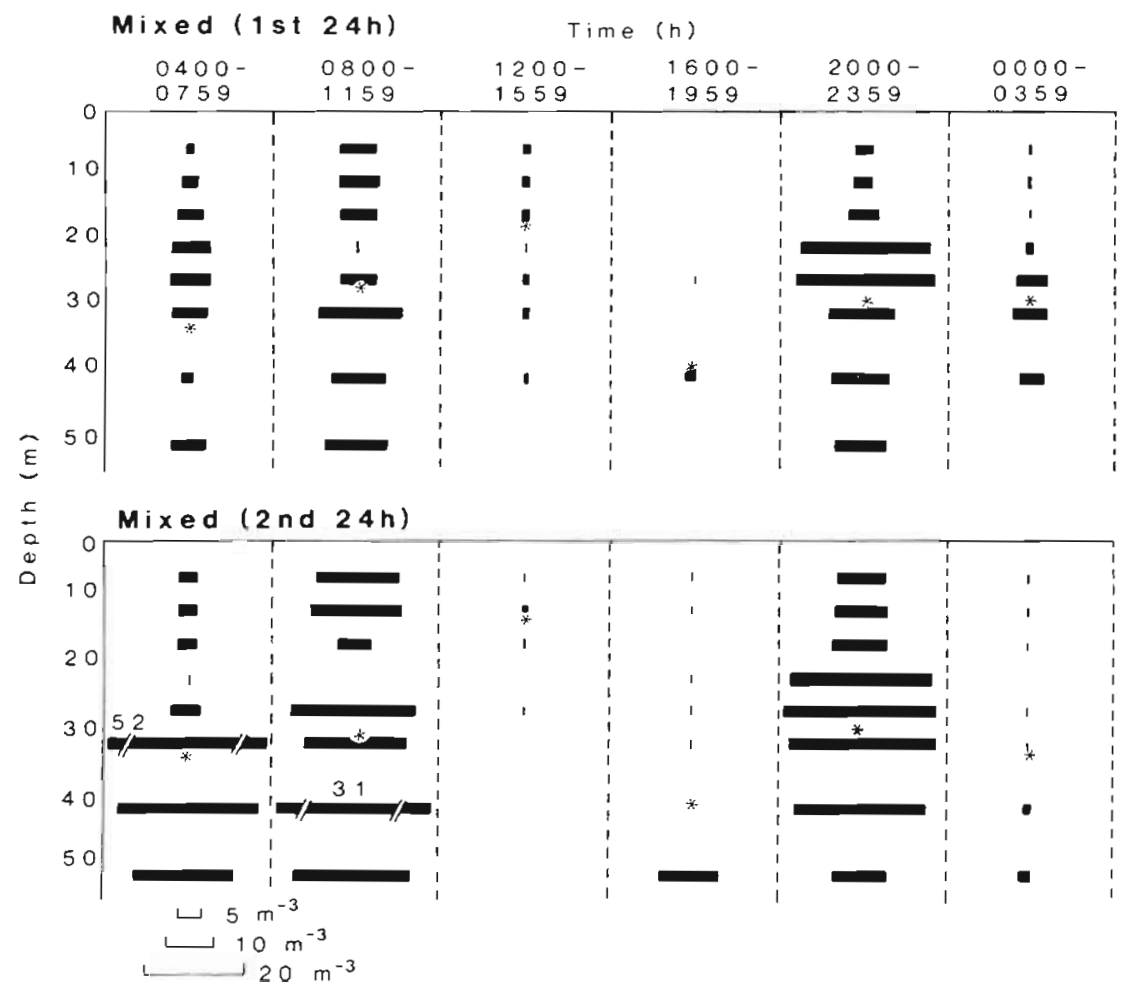

Fig. 11. Neomysis americana vertical distributions over time at the mixed site, Georges Bank, June 1985. Width of each bar is proportional to the density of $N$. americana at that depth; height represents the depth range sampled by each net. Stars indicate the mean depth of the distribution for each time period 
Prey preferences of cod and haddock also differed between the mixed and stratified sites. At the mixed site, although haddock had a slightly broader range of prey items than did cod $\left(B^{\prime}\right.$ for haddock $=2.098$, which was $61 \%$ of $B_{\text {max; }}^{\prime} B^{\prime}$ for $\operatorname{cod}=1.746,54 \%$ of $B_{\text {max }}^{\prime}$ ), there was considerable similarity in their diets. The niche overlap index calculated from the gut contents data indicated relatively similar prey composition $(D=$ 0.686, 17 prey categories, first $24 \mathrm{~h}$ ). Ross (1986) considered species resource use to differ substantially if overlap values were $<0.40$. Numerically dominant prey organisms for both species at the mixed site are indicated in Fig. 10. Calanoid copepods were the

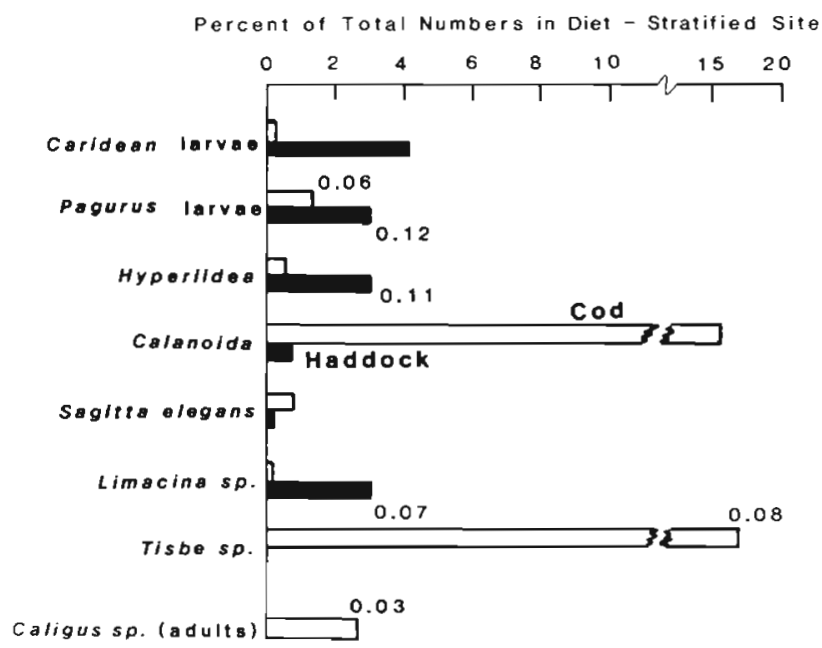

Fig. 12. Gadus morhua and Melanogrammus aeglefinus. Zooplankton prey composition of gut contents of Atlantic cod and haddock from the stratified site, Georges Bank, June 1985. Only zooplankton occurring in $\geq 5 \%$ of the guts examined are included. Total number of guts examined were $229 \mathrm{cod}$ and 130 haddock; total number of prey items identified were 1780 from cod and 2736 from haddock. Numbers at the end of the histogram bars represent the value of a $x^{2}$-based electivity index (see text) for that taxonomic group and fish species. Only those values significantly different from 0 and $>0.01$ are included

dominant taxonomic group by number in the guts of both cod and haddock, with the mysid shrimp Neomysis americana the second most common prey item for both fish species. If these prey items were expressed in terms of biomass, however, $N$. americana would be the most important prey item, given their larger size and weight compared to a calanoid copepod. Fig. 10 also indicates the value of a $\chi^{2}$-based electivity index (Pearre 1982) for each of the major prey items when the index was $>0.01$. N. americana was the most highly selected prey item for both cod and haddock $(p<0.01$ that the index equals 0 ), while haddock also had a lower but significant selection for larval stages of hermit crabs Pagurus sp.

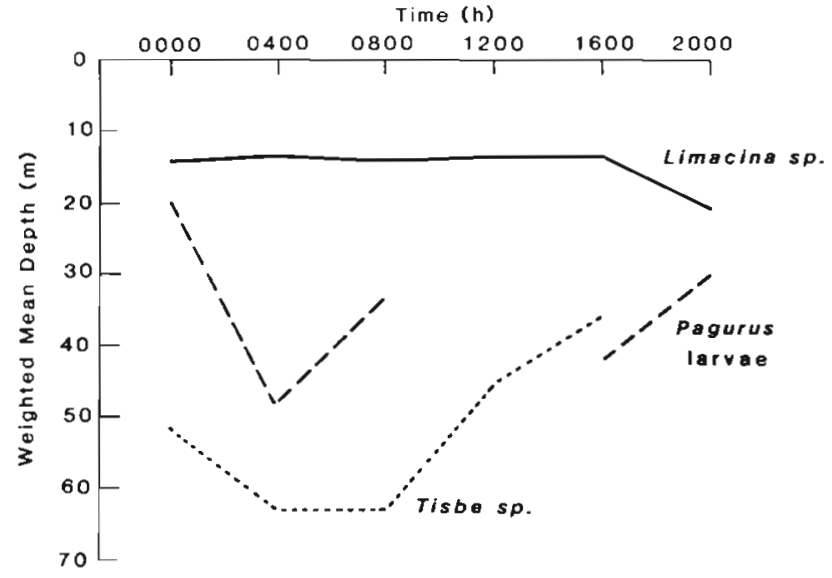

Fig. 13. Mean depths over time of the principal zooplankton prey items of Atlantic cod and haddock at the stratified site, Georges Bank, June 1985. Mean depths for each taxonomic group were calculated from 8 sample depths during each $4 \mathrm{~h}$ time period

At the mixed site, Neomysis americana occurred throughout the water column during the evening and morning periods, at times reaching large densities (>50 $\mathrm{m}^{-3}$ ) particularly at the greater depths (Fig. 11). During the afternoon periods, it was virtually absent from the water column, and was also scarce during the period just after midnight. For each time period, $N$. americana comprised the following percent (by numbers) of the stomach contents of haddock:

\begin{tabular}{cccccc}
$00: 00$ & $04: 00$ & $08: 00$ & $12: 00$ & $16: 00$ & $20: 00$ \\
$-03: 59$ & $-07: 59$ & $-11: 59$ & $-15: 59$ & $-19: 59$ & $-23: 59$ \\
\hline $9.8 \%$ & $37.0 \%$ & $23.4 \%$ & $3.3 \%$ & $18.3 \%$ & $40.5 \%$
\end{tabular}

For cod, $N$. americana comprised between 6.2 and $8.4 \%$ (by number) of the gut contents during each time period, except 12:00-16:00 $\mathrm{h}$ and 20:00-00:00 $\mathrm{h}$, when it comprised $0 \%$ and $20 \%$, respectively.

At the stratified site, haddock also had a broader range of prey than cod $\left(B^{\prime}\right.$ for haddock $=2.491,77 \%$ of $B_{\text {max }}^{\prime} ; B^{\prime}$ for $\operatorname{cod}=1.785,55 \%$ of $B_{\text {max }}^{\prime}$ ). However, there was relatively little overlap in their diets (niche overlap index $D=0.141,18$ prey categories). The 2 gadid species fed upon and had preferences for different groups of zooplankton (Fig. 12). Copepods, both calanoids and the harpacticoid Tisbe sp., were numerically abundant in cod guts. However, when compared with its abundance in the plankton samples, Tisbe sp. was the only group to be highly selected $(p<0.01)$. Cod also showed a high positive selection for larval hermit crabs Pagurus sp., and a lower selection for adults of the copepod ectoparasite Caligus sp., which comprised up to $4 \%$ of the total number of prey. In contrast, copepods formed $1 \%$ of the diet of haddock, the major components instead being caridean shrimp, hyperiid amphipods, Limacina sp. and Pagurus sp. larvae. Of 
these, the most highly selected when compared with their abundance in the plankton were Pagurus larvae, hyperiid amphipods, and Limacina sp. Haddock at this site also had remains of 19 gadidae in their guts, comprising $0.6 \%$ of the total number of prey identified.

The mean depth distributions over time for each of these major prey items are shown in Fig. 13. Tisbe sp. occurred deep in the water, Limacina sp. occurred in the upper portions of the water column about the thermocline, and Pagurus zoea and megalop stages tended to occur at mid-water depths

\section{DISCUSSION}

Conflicting results typify previous studies on the vertical distributions of juvenile cod and haddock in the North Atlantic. Bailey (1975) caught North Sea age-0 (juvenile) haddock at night in mid-water and on the bottom, and concluded that diel vertical migration occurred but that not all of the population was near the surface at night. He also concluded that vertical migration by cod did not occur, since they were caught only on the bottom. Robb (1981) found no evidence for diel vertical migration of either cod or haddock age-0 juveniles in the North Sea. Colton (1965) found the largest numbers of age-0 (juvenile) haddock occurred on Georges Bank within the thermocline at a depth of $20 \mathrm{~m}$, and concluded that there was no evidence for vertical migration. Koeller et al. (1986) also found age-0 haddock on the Scotian Shelf distributed within upperpelagic waters with no indication of vertical migration. However, Scott (1984) did find evidence for diel vertical migration of age-0 haddock about Sable Island, on the northeastern Scotian Shelf, although these fish had probably undergone the transition to the demersal phase. All the above studies were conducted during summer, from late June to August.

The results of the present study are in agreement with those of Colton (1965), at least for age-0 haddock in thermally stratified waters. No significant alteration in depth distribution or in the number of haddock caught between day and night was observed at the stratified site. In isothermal conditions, age-0 haddock were distributed throughout the water column. Haddock longer than $40 \mathrm{~mm}$ were less abundant in mid- and near-surface waters, except during the 2 periods associated with minimal tidal currents. In contrast, the vertical distributions of age-0 cod, in deep water during the day and shallower water at night, were similar at both mixed and stratified sites. Age-0 cod longer than $30 \mathrm{~mm}$ were relatively rare in the pelagic waters of both sites during the day, but abundant at night.

The vertical distributions of age-0 cod and haddock, during the period immediately prior to the transition from pelagic to predominately demersal habitats, represent an intermediate stage between the larval and adult behaviours. Lough (1984) found both cod and haddock larvae distributed almost entirely within the upper $20 \mathrm{~m}$ of the water column at a stratified station on Georges Bank. At an isothermal station, cod and haddock larvae were broadly distributed throughout the water column with no significant diel differences in. depth. In contrast, adult cod undertake extensive vertical migrations at night, while aduit haddock remain associated with the seabed (Brunel 1965, Beamish 1966, Woodhead 1966).

One alternative explanation for the observed variation in vertical distributions deduced from catch data is net avoidance. However, while the numbers of age-0 cod differed significantly between night and day at the mixed site, they were not significantly different at the stratified site. If differences in catch rate were due to net avoidance during the day, such results should occur regardless of location. The numbers of haddock caught were also not significantly different between night and day at either site. Further, if large haddock were unable to avoid capture by the net, then the smaller cod should also be unable to avoid the net, assuming similar swimming abilities and reaction distances between species. The most likely explanation for the reduction in catch during the day, particularly for cod at the mixed site, is that fish moved near to the bottom and became unavailable to the midwater IYGPT gear. The bottom 0 to $5 \mathrm{~m}$ was not sampled at the mixed site, while at the stratified site the region not covered was 0 to $19 \mathrm{~m}$ above the bottom.

The vertical migrations of cod at both sites, and haddock at the mixed site, occurred without variations in temperature or salinity. However, at the stratified site, a large proportion ( $20 \%$; Fig. 4) of cod remained below the themocline. This may represent the acclimation of cod to cooler waters (Tatyankin 1974). The occurrence of haddock at, and above, the thermocline at the stratified site may represent the adult preference for warmer waters compared to cod, as described by Scott (1982).

Light appears to have had a role in the migration of cod, which were on the bottom during the day and in the water column at night. The calculated depths (in meters) for the light intensity at which visual feeding by adult cod ceases (Blaxter 1965) were:

\begin{tabular}{lccccc} 
& Bottom & \multicolumn{4}{c}{ Time (h) } \\
& $\begin{array}{lcccc} \\
\text { depth (m) }\end{array}$ & 08:00 & $12: 00$ & 16:00 & 20:00 \\
\hline Mixed site (1st 24 h) & 60 & 52 & 93 & 90 & 63 \\
Mixed site (2nd 24 h) & 60 & 77 & 94 & 94 & 57 \\
Stratified site & 80 & 63 & 81 & 79 & 68
\end{tabular}


Assuming that this critical light intensity is applicable to juvenile cod, there was sufficient light at the bottom of both sites for feeding to have occurred throughout the day. If this light intensity represents the isolume at which feeding stops and vertical migration begins, the migration could have started earlier and lasted longer at the stratified site, due to the greater bottom depth. However, the sampling strategy we used, in which depth-stratified measurements were conducted within $4 \mathrm{~h}$ time blocks, was too coarse to discriminate such differences in timing between sites.

In contrast, the vertical distributions of haddock at the mixed site did not appear to be entirely related to the diel light cycle. The numbers of haddock caught were significantly correlated with the $M_{2}$ component of the tidal current speed averaged over the period of sampling. The largest catches of haddock in the water column occurred during periods of minimal mean tidal currents. With the semi-diurnal, rotary tides of Georges Bank, 4 minima in tidal current speeds occur per lunar day, with a periodicity of $6.2 \mathrm{~h}$. We observed increased haddock catches during only 2 of these periods due to the periodicity of the sampling design ( $4 \mathrm{~h})$, which was out of phase with the $M_{2}$ tidal period. However, the size-structured vertical distributions (Fig. 7) suggest the diel light cycle may have had an effect on the vertical migration of haddock, with larger fish occurring more extensively throughout the water column during the period of minimal current speeds at night than during the day. The $48 \mathrm{~h}$ sampling series at the mixed site was too short to clearly distinguish these tidal and light effects.

There exist at least 2 hypotheses for the potential relationship of haddock vertical distributions with the tidal current speed. Tidal currents on Georges Bank are strong, ranging from 40 to $80 \mathrm{~cm} \mathrm{~s}^{-1}$ on the Northeast Peak (Butman \& Beardsley 1987). Assuming these juvenile gadids are capable of adult swimming speeds of 2 body lengths $s^{-1}$ (Blaxter 1969), maximum tidal currents can be as great or greater than this swimming speed, resulting in potential advection of fish from the area. One method to reduce such advection would be to remain near the bottom during periods of strongest currents, where friction effects result in lower current speeds. The second hypothesis is that haddock follow the movements of their preferred prey, and it is the prey which migrate off the bottom during periods of reduced current speeds. We favour this second hypothesis, since the preferred prey Neomysis americana was most abundant in the water column during periods of lower tidal currents.

Juvenile and adult stages of Neomysis americana were the preferred prey item for both cod and haddock at the mixed site. It comprised a large fraction of the gut contents of both fish species, and likely contributed to their better physiological condition (as indicated by Fulton's $K$ ) compared with the stratified site, where $N$. americana was generally absent. Cod and haddock were distributed in deep water at the mixed site, with overlapping mean vertical distributions (Fig. 14), coinciding with the vertical distribution of $N$ americana.

Vertical migration of Neomysis americana in response to diel changes in light is well known (Herman 1963, Mauchline 1980). The data of Fig. 11 are consistent with this behaviour, with $N$. americana close to the bottom during the day and unavailable to the plankton gear. However, the times when it was most abundant in the water column, 08:00-12:00 $\mathrm{h}$ and 20:00-00:00 h, corresponded with minima in tidal current speeds. Avoidance of strong currents has been noted for estuarine mysids off California (Mauchline 1980). During these periods of minimal tidal currents, haddock were also widely distributed throughout the water with high rates of food consumption, and $N$. americana comprised a large fraction of their prey. The possibility that the periodic occurrence of $N$. americana in the water column was due to tide-related horizontal advection cannot be disproven, as no broad-scale distribution survey for these mysids was conducted. However, their presence at levels $>6 \%$ in the guts of cod and haddock during all time periods (except
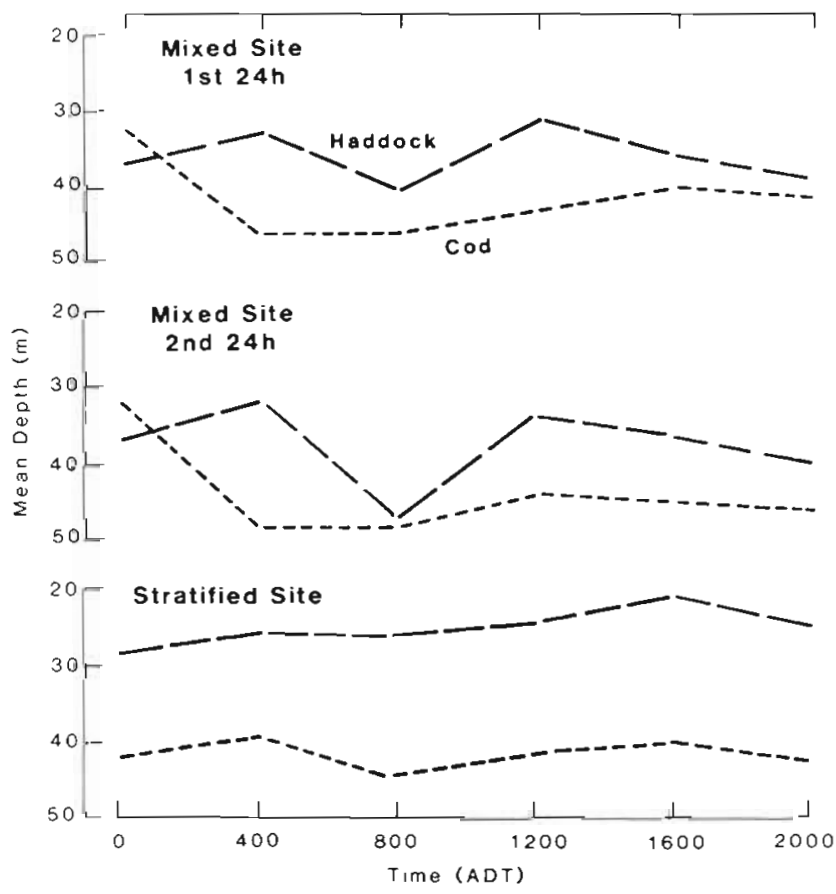

Fig. 14. Gadus morhua and Melanogrammus aeglefinus Mean depths of Atlantic cod and haddock at the mixed site (separated into two 24 h segments) and stratified site, Georges Bank, June 1985. Mean depths were calculated from 3 sample depths within each $4 \mathrm{~h}$ time period, as represented by stars in Figs. 5 and 7 . ADT: Atlantic Daylight Time 
12:00-16:00 h) suggests $N$. americana did occur at the mixed site throughout the $48 \mathrm{~h}$ sampling series.

A bimodal daily pattern in stomach contents weight of haddock was noted by Robb (1981) during a study in the North Sea. He suggested that haddock fed continuously, but that availability of prey governed the amount of food ingested, with fish eggs dominating during daylight, and Appendicularia and Limacinasp. at night. Our results are consistent with this suggestion, with feeding by haddock depending on prey availability.

At the stratified site, zooplankton biomass was significantly lower than at the mixed site, with greater diversity indicating few dominant taxonomic groups. Vertical distributions of the 2 fish species were distinct, with haddock in upper waters while cod tended to remain below the thermocline (Fig. 14). The prey niche breadth of haddock at this site was broader than it was for cod, but there was little overlap in diet between the 2 species. Cod preferred Tisbe sp. and Pagurus larvae, while haddock preferred Limacina sp., hyperiid amphipods, and Pagurus larvae. The vertical distributions of cod and haddock reflected the relative distributions of their preferred prey; cod and Tisbe sp. cooccurred in deep water, haddock and Limacina sp. cooccurred in shallow water, and Pagurus larvae occurred in mid-water between the mean depths of both fish species. The occurrence of age-0 gadids (mostly cod when identifiable) in the guts of age-0 haddock at the stratified site suggests that availability of suitable prey may have been limited. Predation by age-0 gadids on other age-0 gadids has not been noted before on Georges Bank to our knowledge. Further, adults of the copepod ectoparasite Caligus sp. comprised a large proportion of the gut contents of cod at the stratified site, even though they occurred in the water at lower densities and were less of a parasite burden than at the mixed site (Neilson et al. 1987).

Such differences in vertical distribution and behaviour between age-0 cod and haddock at mixed and stratified sites may act to reduce interspecific competition. When prey are plentiful, as at the mixed site, there is little pressure to reduce competition and separate the feeding niches. However, when prey are scarce, as appears to have occurred at the stratified site, the distributions of cod in deep water and haddock in shallow water about the thermocline, possibly due to different temperature preferences, may provide different prey resources for each fish species and reduce interspecific competition. Since few other fish species were caught, the principal competition for prey would be between cod and haddock. Such convergence of diet when prey are abundant, and separation when prey are scarce has been noted by Harrington \& Harrington (1961) for fishes feeding on mosquito larvae in coastal salt marshes, and by Thorman (1982) for estuarine fish species on the west coast of Sweden. Courtois et al. (1982) have also concluded that vertical separation results in reduced interspecific competition of fish larvae in the St Lawrence River estuary.

These results have important implications for the design of surveys to estimate abundances of age-0 cod and haddock during the pelagic stage, in particular on Georges Bank. Colton (1965) found no evidence for vertical migration of age-0 haddock in a stratified water mass and concluded that for survey purposes, it would be sufficient to sample from the surface to the thermocline. Koeller et al. (1986) used this methodology for surveys of age-o haddock on the Scotian Shelf. Our results indicate, however, that vertical migrations of age-0 cod and haddock do occur. Those of cod appear to occur in phase with the diel light cycle. The migrations of haddock, however, and indeed the mean depth distribution at a given location, may not be predictable a priori. Instead, it may depend on a combination of thermal structure, interspecific competition and the availability of prey, and the tidal current speed.

Buckley \& Lough (1987) studied prey densities and growth of larval cod and haddock during spring on Georges Bank. They found, using RNA-DNA ratio analyses, that condition and recent growth rates of both cod and haddock were significantly greater at 2 stratified sites compared with a well-mixed site on the southern flank of the Bank. This was attributed to higher available prey biomass at the stratified sites, particularly above the thermocline. Our results are consistent with Buckley \& Lough's (1987) conclusions, with greater numbers and better condition of age-0 (postlarval) cod and haddock at the location with the highest densities of available prey. However, our results differ from theirs in the location of this high prey biomass, which was at the mixed site rather than at the stratified station. We suggest there may be a switch in the location of conditions most favorable to the growth of early stages of cod and haddock, from stratified waters about the flank of the Bank in spring, to mixed and frontal waters surrounding the cap of the Bank during summer. The common factor is the availability of suitable prey. Small zooplankton appropriate for larval cod and haddock occur at higher densities about the thermocline in stratified waters during spring. In summer, the high primary production of the mixed area, and the particularly high phytoplankton biomass of the frontal zone (O'Reilly et al. 1987), may lead to enhanced benthic biomass, including such suprabenthic zooplankton as Neomysis americana. Such an influence of a frontal zone on benthic biomass has been noted for the Bay of Fundy by Daborn (1986). However, a broader survey of prey biomass and juvenile gadid distributions than was the objective of this study will be necessary to elaborate on this hypothesis. 
Acknowledgements. We thank R. Stephenson, S. Campana, J. S. Scott and K. Frank for their critical reviews and suggestions for improvement of this paper J. Loder and D. Greenberg graciously provided the parameters to calculate tidal current speeds. R. Losier and P. Perley assisted with the technical work at sea, onshore, and with the data analyses. J. Reid and P. Hurley were invaluable for their help with the sampling gear. Thanks also go to the crew of the Alfred Needler' and 'Lady Hammond', to J. Hurley and B. Best for typing the manuscript, and to F. Cunningham for drafting the figures.

\section{LITERATURE CITED}

Bailey, R. M. (1975). Observations on diel behaviour patterns of North Sea gadoids in the pelagic phase. J. mar. biol. Ass. U.K. 55: 133-142

Beamish, F. W. H. (1966). Vertical migration by demersal fish in the Northwest Atlantic. J. Fish. Res. Bd Can. 23: 109-139

Blaxter, J. H. S. (1965). Effect of change of light intensity on fish. ICNAF Spec. Publ. 6: 647-661

Blaxter, J. H. S. (1969). Swimming speeds of fish. FAO Fish. Rep. No. 62, Vol. 2: 69-100

Brunel, P. (1965). Food as a factor or indicator of vertical migrations of cod in the western Gulf of St. Lawrence. ICNAF Spec. Publ. 6: 439-448

Bowman, R. E. (1981). Food of 10 species of Northwest Atlantic juvenile groundfish. Fish. Bull. U.S. 79: 200-206

Buckley, L. J., Lough, R. G. (1987). Recent growth, biochemical composition, and prey field of larval haddock (Melanogrammus aeglefinus) and Atlantic cod (Gadus morhua) on Georges Bank. Can. J. Fish. Aquat. Sci. 44: $14-25$

Butman, B., Beardsley, R. C. (1987). Physical oceanography. In: Backus, R. H. (ed.) Georges Bank. MIT Press, Cambridge, p. 88-98

Colton, J. B., Jr (1965). The distribution and behaviour of pelagic and early demersal stages of haddock in relation to sampling techniques. ICNAF Spec. Publ. 6: 317-333

Colton, J. B., Jr, Smith, W G., Kendall, A. W., Berrien, P. L., Fahay, M. P. (1979). Principal spawning areas and times of marine fishes, Cape Sable to Cape Hatteras. Fish. Bull. U.S. 76: 911-915

Colwell, R. K., Futuyma, D. J. (1971). On the measurement of niche breadth and overlap. Ecology 52: 567-576

Courtois, R, Simoneau, M. Dodson, J. J. (1982). Interactions multispécifiques: répartition spatio-temporelle des larves de capelan (Mallotus villosus), d'éperlan (Osmerus mordax) et de hareng de l'Atlantique (Clupea harengus harengus) au sein de la communauté planctonique de l'estuaire moyen du Saint-Laurent. Can. J. Fish. Aquat. Sci. 39: 1164-1174

Daborn, G. R. (1986). Effects of tidal mixing on the plankton and benthos of estuarine regions of the Bay of Fundy. In: Bowman, M. J., Yentsch, C. M., Peterson, W. T (eds.) Tidal mixing and plankton dynamics. Lecture Notes on Coastal and Estuarine Studies, Vol. 17, Springer-Verlag, Berlin, p. 390-413

Fogarty, M. J., Sissenwine, M. P., Grosslein, M. D. (1987). Fish population dynamics. In: Backus, R. H. (ed.) Georges Bank. MIT Press, Cambridge, p. 494-507

Greenberg, D. A. (1983). Modelling the mean barotropic circulation in the Bay of Fundy and Gulf of Maine. J. phys. Oceanogr. 13: 886-904
Harrington, R. W., Jr, Harrington, E. S. (1961). Food selection among fishes invading a high subtropical salt marsh: from onset of flooding through the progress of a mosquito brood. Ecology 42: 646-666

Hennemuth, R. C., Palmer, J. C., Brown, B. E. (1980). A statistical description of recruitment in eighteen selected fish stocks. J. Northwest Atl. Fish. Sci. 1: 101-111

Herman, S. S. (1963). Vertical migration of the opossum shrimp Neomysis americana Smith. Limnol. Oceanogr. 8: 228-238

Hurlbert, S. H. (1978). The measurement of niche overlap and some relatives. Ecology 59:67-77

Koeller, P. A., Hurley, P. C. F., Perley, P., Neilson, J. D. (1986) Juvenile fish surveys on the Scotian Shelf: implications for year-class size assessments. J. Cons. int. Explor. Mer 43: $59-76$

Loder, J. W., Greenberg, D. A. (1986). Predicted positions of tidal fronts in the Gulf of Maine Region. Cont. Shelf Res. 6: $397-414$

Lough, R. G. (1984). Larval fish trophodynamic studies on Georges Bank: sampling strategy and initial results. Flodevigen rapportser. 1: 395-434

Mauchline, J. (1980). The biology of mysids and euphausids. Adv. mar Biol. 18: 1-677

May, R. C. (1974). Larval mortality in marine fishes and the critical period concept. In: Blaxter, J. H. S. (ed.) The early life history of fish. Springer-Verlag, New York, p. 3-19

Neilson, J. D., Perry, R. I., Scott, J. S., Valerio, P. (1987). Interactions of caligid ectoparasites and juvenile gadids on Georges Bank. Mar. Ecol. Prog. Ser. 39: 221-232

O Reilly, J. E., Evans-Zetlin, C., Busch, D. A. (1987). Primary production. In: Backus, R. H. (ed.) Georges Bank. MIT Press, Cambridge, p. 220-233

Overholtz, W. J., Sissenwine, M. P., Clark, S. H. (1986). Recruitment variability and its implications for managing and rebuilding the Georges Bank haddock (Melanogrammus aeglefinus) stock. Can. J. Fish. Aquat. Sci. 43: $748-753$

Pearre, S., Jr (1973). Vertical migration and feeding in Sagitta elegans Verrill. Ecology 54: 300-314

Pearre, S., Jr (1982). Estimating prey preference by predators: uses of various indices, and a proposal of another based on $\chi^{2}$. Can. J. Fish. Aquat. Sci. 39: 914-923

Reid, J. G. G., Hurley, P. C. F., O'Boyle, R. N. (1987). MININESS: a self-trimming multiple opening and closing plankton net frame design. Proc. IEEE, Oceans '87. Halifax, p. $466-471$

Robb, A. P. (1981). Observations on the food and diel feeding behaviour of pelagic 0-group gadoids in the northern North Sea. J. Fish. Biol. 18: 183-194

Ross, S. T (1986). Resource partitioning in fish assemblages: a review of field studies. Copeia 1986: 352-388

Scott, J. S. (1982). Depth, temperature and salinity preferences of common fishes of the Scotian Shelf. J. Northwest Atl. Fish. Sci. 3: 29-39

Scott, J. S. (1984). Short-term changes in distribution, size and availability of juvenile haddock around Sable Island off Nova Scotia. J. Northwest Att. Fish. Sci. 5: 109-112

Shannon, C. E., Weaver, W (1963). The mathematical theory of communication. University of Illinois Press, Urbana

Sherman, K., Smith, W., Morse, W., Berman, M., Green, J., Ejsymont, L. (1984). Spawning strategies of fishes in relation to circulation, phytoplankton production, and pulses in zooplankton off the northeastern United States. Mar. Ecol. Prog. Ser. 18: 1-19

Sissenwine, M. P. (1984). Why do fish populations vary? In: May, R. M. (ed.) Exploitation of marine communities. 
Dahlem Konferenzen 1984. Springer-Verlag, Berlin, p. 59-94

Sissenwine, M. P., Cohen, E. B., Grosslein, M. D. (1984). Structure of the Georges Bank ecosystem. Rapp. P.-v. Réun. Cons. int. Explor. Mer 1.83: 243-254

Smith, W G., Morse, W. W. (1985). Retention of larval haddock Melanogrammus aeglefinus in the Georges Bank region, a gyre-influenced spawning area. Mar. Ecol. Prog. Ser 24: $1-13$

Tat'yankin, Yu. V (1974). The effect of the preliminary adaptation temperature on the distribution of juvenile cod (Gadus morhua morhua) and pollock (Pollachius virens) within a temperature gradient. J. Ichthyol. 14: $755-760$

Templeman, W (1972). Year-class success in some North Atlantic stocks of cod and haddock. ICNAF Spec. Publ. 8: $223-238$

Thorman, S. (1982). Niche dynamics and resource partitioning in a fish guild inhabiting a shallow estuary on the Swedish west coast. Oikos 39: 32-39

Woodhead, P. M. J. (1966). The behaviour of fish in relation to light in the sea. Oceanogr. mar. Biol. A. Rev. 4: 337-403

This article was presented by Dr D. J. Wildish; it was accepted for printing on September 9, 1988 